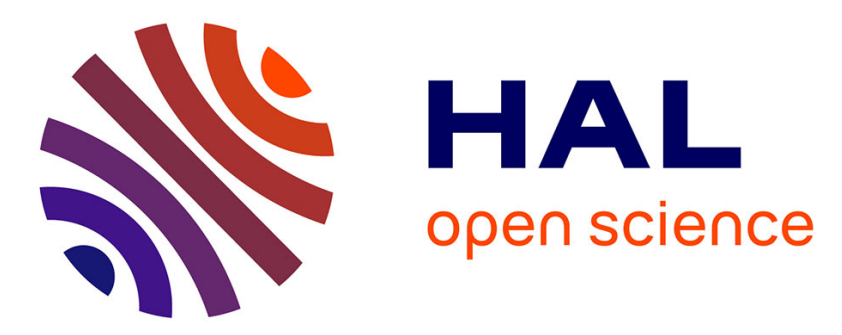

\title{
Two Greenlandic Sea Ice Lists and Some considerations Regarding Inuit Sea Ice Terms
}

\author{
Nicole Tersis, Pierre Taverniers
}

\section{To cite this version:}

Nicole Tersis, Pierre Taverniers. Two Greenlandic Sea Ice Lists and Some considerations Regarding Inuit Sea Ice Terms. I.Krupnik et al. SIKU: Knowing Our Ice, Springer Science, pp.413-426, 2010. halshs-00724585

\author{
HAL Id: halshs-00724585 \\ https://shs.hal.science/halshs-00724585
}

Submitted on 21 Aug 2012

HAL is a multi-disciplinary open access archive for the deposit and dissemination of scientific research documents, whether they are published or not. The documents may come from teaching and research institutions in France or abroad, or from public or private research centers.
L'archive ouverte pluridisciplinaire HAL, est destinée au dépôt et à la diffusion de documents scientifiques de niveau recherche, publiés ou non, émanant des établissements d'enseignement et de recherche français ou étrangers, des laboratoires publics ou privés. 
Article publié dans I. Krupnik et al. (eds.), 2010, SIKU: Knowing Our Ice, Springer

Science+Business Media B.V. pp.413-426.

\section{Two Greenlandic Sea Ice Lists and Some Considerations Regarding Inuit Sea Ice Terms Nicole Tersis (SeDyL-CNRS) and Pierre Taverniers (Méteo-France)}

The following two lists of the Greenlandic Inuit sea ice terms are the result of field research in Greenland, and they do not pretend in any way to be exhaustive. The first list relates to the language of west Greenland, spoken by approximately 52,000 people, and recognized since 1979 as the official language of Greenland under the name of Kalaallisut (Berthelsen et al. 2004, Sadock 2003). The version presented here was recorded in the community of Qeqertaq in the Disko Bay area of northwest Greenland (see Taverniers in SIKU :Knowing Our ice) and it reflects what is called the "northwest Greenlandic" subdialect of the Kalaallisut language (Dorais 2003:136). The second list presents the terms of the language of east Greenland, or tunumiisut, spoken by approximately 3,500 people in the municipalities of Ammassalik and Ittoqqortoormiit (Gessain et al. 1986, Robbe and Dorais 1986, Victor and RobertLamblin 1989, 1993). These two languages are part of a continuum of Inuit dialects that extends from northern Alaska to Greenland, spoken by approximately 80,000 people. This variety of dialects belongs to the linguistic family known as Eskaleut (Eskimo-Aleut).

All of the dialectal forms of this language continuum belong to the polysynthetic type, in the sense that a unique word base (verb or noun) is followed by a large number of morphemes (Mahieu and Tersis 2009). This results in several characteristics that we find in the Inuit (Eskimo) words for sea ice: the roots that stand alone are limited in a synchronic analysis, while there is a large number of derived forms (see also Johns in SIKU :Knowing Our ice). The same base word can also bring up a series of more or less fossilized forms, as the examples derived from the base word siku, ice, show.We could even build other terms, which shows that some lexical formations are really open lists: sikkiar-poq: [he, she] goes to a place where there is sea ice; sikorip-poq: sea ice is good, sikorlup-poq: sea ice is bad (thin and unsafe), etc.

Inuit sea ice words are explanatory and descriptive commentaries to the physical reality that they name, that is, to the many types of ice, ice processes, and associated phenomena. They often reveal a perception or knowledge that relates to people's observations of the environment, often for many generations. They can equally refer to the function or the description of the object or entity described in the term.

Whenever possible, we found it essential to provide an analysis of the components of derived terms, as well as the translation of each unit. Some interpretations of the components of terms that are more hypothetical are followed by a question mark. Differences that may exist between the final form of the word and the analyzed elements are due to morphophonological rules (elisions, vowel, or consonant assimilations). This way of presenting the material allows us to demonstrate the transparence and expressiveness of numerous Greenlandic sea ice terms.

References to the Comparative Eskimo Dictionary of proto-forms (Fortescue 
et al. 1994) have been introduced in certain cases where there are documented differences between the word in Greenlandic and other dialects. The lexicon in Kalaallisut adopts the official Greenlandic orthography, while the lexicon in Tunumiisut is rendered phonologically because the orthography of this language is not fixed. In addition, verbs are presented in their indicative form $(-p o q /-v o q)$ in Kalaallisut (cf. aagup-poq), and in their radical form in Tunumiisut, followed by a dash (siki-freeze).

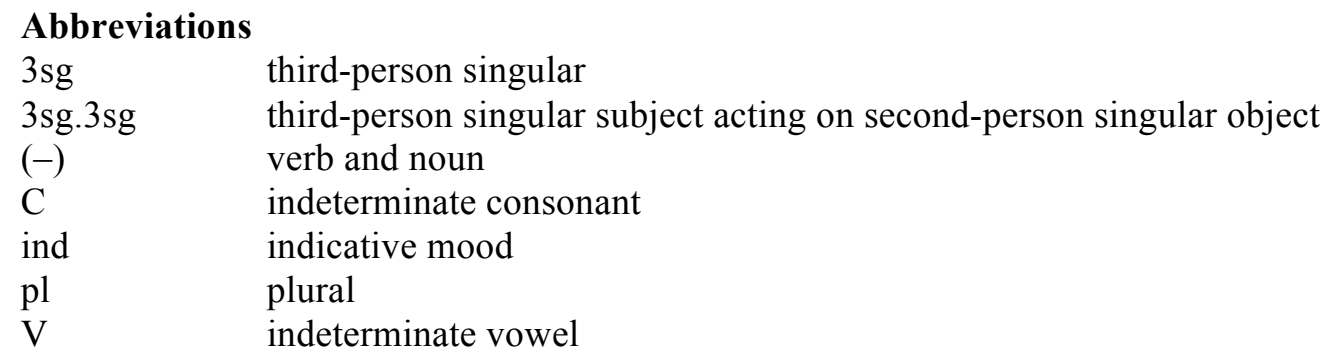

\section{Qeqertaq Sea Ice Dictionary (2008) - Kalaallisut} (Western Greenlandic)

This list was compiled in 2008 in the community of Qeqertaq by Pierre Taverniers and his local collaborators, Aka Tobiassen, Thora Tobiassen, Zakkak Tobiassen (see Taverniers this volume). It has been revised and analyzed by Nicole Tersis in collaboration with Naja Frederikke Trondhjem (Trondhjem 2009), from the University of Copenhagen (see Acknowledgments).

aaguppoq: the hole in sea ice enlarges.

/aap-gup-poq melt-tend to-ind.3sg/

aakkarneq: melted sea ice (by current or weather action). /aap-kkar-neq melt-causative- abstract participium/

aakkarpoq: [sea ice] melts (by current or weather action). /aap-kkar-poq melt-causative-ind.3sg/

aallaaniagaq: there is an animal (seal or sea mammal) in a hole in sea ice. /aallaa-niar-gaq shoot -will-passive participium/ one, which should be shoot aanneq: fracture (any break or rupture through fast ice or a single floe resulting from deformation processes).

/aap-neq melt-abstract participium/

aannersaq: small polynya (polynya: any non-linear shaped opening enclosed in ice).

/aap-ner-saq melt-abstract participium-passive participium/ which are melted

allu: seal breathing hole in sea ice.

allualiorpoq: [he, she] builds an alluaq (fishing hole chipped out in sea ice). /alluaq-lior-poq fishing hole-make-ind.3sg/ 
alluaq: fishing hole chipped out in sea ice.

/allu-aq seal breathing hole-alike/

allusiorpoq: [he, she] looks for an allu (seal breathing hole in sea ice).

/allu-sior-poq breathing hole-look for-ind.3sg/

ammalataq: hole in sea ice built by seal or sea mammal.

/amma-la-taq be open-little?-passive participium/

ammavoq: there is a passage-way through sea ice which is navigable by boat.

/amma-voq be open (state)-ind.3sg/

appakarpoq: [a boat] moves through sea ice.

/appakar-poq come through (often a narrow pass)-ind.3sg/

aqqartarfik: passage from land to fast ice for sled (through icefoot and tide crack). /aqqar-tar-fik go down- habitual-place/

aserorterpaa: [a boat or an iceberg] breaks it [sea ice].

/aseror-ter-paa be broken-gradually-ind.3sg.3sg/

ilarpaa: [he, she] removes ice from a fishing hole chipped out in sea ice with an ilaat (bailer).

/ilar-paa remove ice-ind. $3 \mathrm{sg} .3 \mathrm{sg} /$

ilaat: bailer used to remove ice from a fishing hole chipped out in sea ice.

/ilar-ut remove ice-mean for doing/

iluliaq: iceberg (a massive piece of ice, more than $5 \mathrm{~m}$ above sea level, which has broken away from a glacier); when surrounded by solid fast ice, icebergs are climbed and used as a promontory to watch sea ice (to hunt and travel), also used to provide fresh water. At spring, when sea ice becomes less solid, iceberg moved by current break sea ice and open leads.

ilulissap eqqaa: area around the iceberg (where sea ice is often thin and unsafe, or deformed or hummocked).

/ilulissa-p eqqaa iceberg-genitive around.3sg/

iluliusaq: bergy bit (a large piece of floating glacier ice, generally showing less than $5 \mathrm{~m}$ above sea level but more than $1 \mathrm{~m}$ and normally about 100-300 sq. $\mathrm{m}$ in area). The area around a bergy bit is a good place to set net under sea ice to catch seals. /iluliaq-usaq iceberg-look like/

imarnersaq: puddle (an accumulation on ice of melt-water, mainly due to melting snow, but in the more advanced stages also to the melting of ice). Refers to

imaq: sea.

/imar-ner-saq sea-abstract participium-passive participium/

imarorpoq: sea becomes ice free. Refers to imaq: sea.

/imaq-ror-poq sea-become-ind.3sg/ 
inguneq: ridge (a line or wall of broken ice forced up by pressure).

/ingu-neq form pressure ridges-abstract participium/

inguvoq: there is a pressure process by which sea ice is deformed.

/ingu-voq form pressure ridges-ind.3sg/

itivippoq: [he, she] travels by land and sea ice.

/itivip-poq pass over-ind.3sg/

kassoq: translucent piece of floating glacier ice (melted water which has re-frozen in a glacier's crack).

kikkuleq: seal hole in sea ice.

manerak: flat area on sea ice.

/manip-rak be flat-area/

Cf. Proto Eskimo *qar "area or part (in direction)" (Fortescue et al. 1994:421).

maniillat: uneven ice or deformed ice (ice which has been squeezed together and in places forced upwards; ridged ice or hummocked ice).

/manip-ip-lat be flat-negative-passive participium.pl/

maniippoq: [land, sea ice] is not flat.

/manip-ip-poq be flat-negative-ind.3sg/

manippoq: [land, sea ice] is flat.

/manip-poq be flat-ind.3sg/

naggutit: small pieces of sea ice.

/naggur-tit break into pieces-participium.pl/

nallorpoq: [sea ice, fast ice] breaks up in many pieces.

/nallor-poq break (in several places)-ind.3sg/

napasoq: vertical chunk of ice installed close to a fishing hole chipped out in sea ice used to fix a fishing line and also to built a placemark.

/napa-soq be standing-participium/

nilat: small pieces of glacier ice; collected to provide fresh water. When included in sea ice they make uneven ice.

nilattarpoq: [he, she] collects nilat (on the shore or on the sea when there is no fast ice).

/nilat-tar-poq pieces of glacier ice-collect-ind.3sg/

nivinngarpaa: [he, she] sets a net under sea ice.

/nivinngar-paa hang up-ind. $3 \mathrm{sg} .3 \mathrm{sg} /$

nutarneq: recently formed sea ice. 
/nutaar-neq new- abstract participium/

paarmuliaq: seal which crawls on sea ice.

/paarmur-liaq crawl- made thing/

puttaaq: small piece of floating sea ice. Usually ice cake (any relatively flat piece of sea ice less than $20 \mathrm{~m}$ across) or small ice cake (an ice cake less than $2 \mathrm{~m}$ across). Cf. putta- be afloat

puttaarpoq: [he, she] jumps from a puttaaq to an other.

/puttaar-poq jump from a piece of floating sea ice to another-ind.3sg/

puttaqut: float made with a wood piece fixed on the long-handled (wood) ice chipping tool to set net under sea ice.

/putta-qut be afloat-instrument/

puttineq: melting snow area on sea ice.

Cf. pugtípoq, puvfípoq, Water oozes up through the ice, forming a king of slush with the snow on it, Schultz-Lorentzen 1927:197.

Cf. pui- swell

puttippoq: sea ice surface becomes wet (melting snow).

/pui-tip?-poq rise to surface-cause?-ind.3sg/

qaanngorsiorneq: a way onto the qaanngoq (icefoot).

/qaanngor-sior-neq icefoot-look for-abstract participium/

qaanngoq: icefoot (a narrow fringe of ice attached to the coast, unmoved by tides and remaining after the fast ice has moved away).

qaanngueruppoq: the qaanngoq (icefoot) breaks up (usually in spring, after have been submerged by high tides).

/qaanngoq-erup-poq icefoot-have no more-ind.3sg/

qaanngunippoq: the qaanngoq (icefoot) forms.

/qaanngoq-nip-poq icefoot-get-ind.3sg/

qaatersuarpoq: [a person or a dog] falls through sea ice.

/qaaser-ter-rsuar-poq? be wet-gradually-much-ind.3sg/

qaatsinneq: wet snow area or flooded ice area or re-frozen area along the tide crack (crack at the line of junction between an immovable icefoot and fast ice, the latter subject to rise and fall of the tide).

Cf. Proto-Inuit *qaaptet- "overflow (water over ice)" in connection with *qaa "top or surface of s.th" (Fortescue et al. 1994:274).

qaattarpoq: [he, she] places a net under sea ice.

/qaattar-poq hunt with a net-ind.3sg/

In some dialect (Upernavik) qaattar- "catch a seal by net" 
qinuuvoq: there is slush (snow that is saturated and mixed with water on land or ice surfaces, or as a viscous floating mass in water after a heavy snowfall).

/qinoq-u-voq snow on the ice-be-ind. $3 \mathrm{sg} /$

qitulligarpoq: [sea ice surface] has an undulation (aged ridge: ridge which has undergone considerable weathering. These ridges are best described as undulations). /qitulligar-poq bend when someone treads on it-ind.3sg/

quasaq: slippery ice (often bare ice).

quasaliarpoq: [he, she] goes to slippery ice.

/quasaq-liar-poq slippery ice-go to-ind.3sg/

quasasiorpoq: [he, she] is on slippery ice.

/quasaq-sior-poq slippery ice-experience-ind.3sg/

sarfaq: current. Current under sea ice thins the sea ice and makes it dangerous.

sassat: sea mammals trapped by ice (when sea ice forms) and who have only a small hole or polynia to breath.

seersinneq: sea ice (and river ice) formed in sheets or thin layers.

/seer-sip-neq sizzle-cause?-abstract participium/

seersippoq: sea ice (and river ice) forms in sheets or thin layers.

/seer-sip-poq sizzle-cause?-ind.3sg/

Cf. seersoq something that flashes; willow, Schultz-Lorentzen 1927:212.

sermiisorpoq: [he, she] collects blocks (to provide fresh water) on an iceberg (only if iceberg is surrounded by solid fast ice).

/sermeq-isor-poq ice block-fetch-ind.3sg/

sequmippoq: [sea ice] is broken (by waves) in a multitude of small pieces.

/sequmit-poq break into pieces-ind.3sg

/

sequmissimavoq: fast ice is broken up.

/sequmit-sima-voq break into pieces-perfective-ind.3sg/

sikkiarpoq: [he, she] goes to a place where there is sea ice.

/siku-liar-poq ice-go to-ind.3sg/

sikorippoq: sea ice is good (more than $20 \mathrm{~cm}$ in thickness).

/siku-gip-poq ice-be good-ind.3sg/

sikorluppoq: sea ice is bad (thin and unsafe).

/siku-rlup-poq sea ice-have a bad-ind.3sg/

sikkuppaa: [a boat] is beset (surrounded by ice and unable to move).

/siku.up-paa ice.with it-ind. $3 \mathrm{sg} 3 \mathrm{sg} /$ 
sikkussaavoq: it is trapped by ice.

/siku.up-saq.u-voq ice.with it-passive participium.be-ind.3sg/

sikkutak: thick ice cake (any relatively flat piece of sea ice less than $20 \mathrm{~m}$ across) or thick small floe (any relatively flat piece of sea ice 20-100 m across).

sikutaq: ice cake (any relatively flat piece of sea ice less than $20 \mathrm{~m}$ across).

/siku-taq ice-piece of/

sikoqasaarpoq: there are floes (or floating glacier ice) everywhere.

/siku-qa-saar-poq ice-have-a few here and there-ind.3sg/

sikulaaq: recently formed sea ice.

/siku-laaq ice-new/

sikoqannginnersaq: ice free area inside pack ice after fast ice break up.

/siku-qa-nngin-ner-saq ice-have-negative-abstract participium-passive participium/

sikorsuarsiorpoq: [a boat] navigates through ice (sea ice or floating glacier ice).

/siku-rsuar-sior-poq ice-big-move about in-ind.3sg/

sikorsuit: thick sea ice (in an isfjord where sea surface temperature is cold because of floating glacier ice and where sea ice forms early and becomes thick).

/siku-rsuit ice-big.pl/

siku: ice (sea ice, river ice, lake ice, ice-cream)

sikuarllaaq: dark nilas (a thin elastic crust of ice) few mm thick.

/sikuar-llaaq dark nilas-newly/

sikuaq: dark nilas (a thin elastic crust of ice) $1-5 \mathrm{~cm}$ thick.

sikuarpoq: sikuaq forms.

/sikuar-poq form nilas-ind.3sg/

sikuerpoq: sea ice breaks up and goes away.

/siku-er-poq ice-remove-ind.3sg/

sikueruppoq: sea is ice-free.

/siku-erup-poq ice-have no more-ind.3sg/

sikuiuippoq: there is sea ice "which doesn't melt": old ice (sea ice which has survived at least one summer's melt).

/siku-er-juip-poq ice-remove-never-ind.3sg/

sikuiuitsoq: sea ice "which doesn't melt": old ice (sea ice which has survived at least one summer's melt).

/siku-er-juit-soq ice-remove-never-participium/

sikujartuaarpoq: sea ice forms and becomes thicker (on several days). 
/siku-jartuaar-poq form ice-gradually-ind.3sg/

sikujumaataarpoq: sea ice delays in forming.

/siku-jumaataar-poq form ice-a long time to get-ind. $3 \mathrm{sg} /$

sikujuippoq: there is no more sea ice.

/siku-juip-poq form ice-never-ind.3sg/

sikuliarpoq: [he, she] goes to the fast-ice.

/siku-liar-poq ice-go to-ind.3sg/

sikuliaq: recently formed sea ice.

/siku-liaq ice-made/

sikumukarpoq: [he, she] goes to the fast-ice.

/siku-mu-kar-poq ice-allative-go to-ind.3sg/

sikumiippoq: [he, she, it] is on the fast-ice.

/siku-mi-ip-poq ice-locative-be-ind.3sg/

sikunippoq: floating pieces of sea ice arrive (moved by wind or current) when the sea was ice free.

/siku-nip-poq ice-get-ind.3sg/

sikusiorpoq: [boat] moves through sea ice.

/siku-sior-poq ice-move about in-ind.3sg/

sikut (pl): drifting ice (pieces of sea ice or small floating glacier ice).

sikutanngueruppoq: there is no ice at all on the sea.

/siku-taq-nguaq-erup-poq ice-piece of-little-have no more-ind.3sg/

sikuvoq: fast ice is formed.

/siku-voq form ice-ind. $3 \mathrm{sg} /$

sinaaliarpoq: [he, she] reaches the sinaaq by travelling on the fast ice.

/sinaaq-liar-poq ice edge-go to-ind.3sg/

sinaalippoq: [boat] reaches the sinaaq.

/sinaaq-lip-poq ice edge-reach-ind.3sg/

sinaaniippoq: [he, she] is at the sinaaq.

/sinaaq-ni-ip-poq ice edge-locative-be-ind.3sg/

sinaaq: fast ice edge (the demarcation between fast ice and open water).

sinaasiorpoq: [he, she] is walking or travelling along the sinaaq.

/sinaaq-sior-poq ice edge-move about in-ind.3sg/

sinaasserpoq: the sinaaq forms after break up. 
/sinaaq-ser-poq ice edge-move along-ind.3sg/

tiggunnerit: small pieces of ice (sea ice or floating glacier ice) compacted by wind or current.

/tiggut-ner-it split- abstract participium-pl/

toorpaa: [he, she] chips ice (sea ice or glacier ice) with a tooq.

/toor-paa chip ice with a tool-ind.3sg.3sg/

tooq: long-handled (wood) ice chipping tool; to chip an ice fishing hole on fast ice; to test sea ice strength when walking on an area which can be dangerous; to set a net: the tooq is pushed under sea ice from a fishing hole to an other (using puttaqut); to collect blocks from an iceberg to provide fresh water.

uisaavoq: [he, she] goes away on a floe when fast ice breaks up.

/uiar-saq-u-voq go around headland-passive participium-be-ind.3sg/

umiarluppoq: [he, she] uses a small ice cake as a boat (moves by paddling). Refers to umiaq: (boat); to reach a seal which was shot from the fast ice edge (using a rifle as a paddle).

/umiar-rlup-poq boat-have a bad-ind.3sg/

unerraq: seal's track on sea ice.

/uniar-gaq? drag-passive participium?/

unneraarsuppaluk: grate sound or creak from sea ice moving up and down along the icefoot (by wave or tide action).

/unneraarsuk-paluk the spirit of the beach-sound of/

uukkaappaa: fast ice edge breaks up.

/uukkar-up-paa calve-for him-ind.3sg. $3 \mathrm{sg} /$

uuttoq: seal which basks in the sun on fast ice.

/uut-toq bake-participium/ one who bakes himself on the ice in the sun

uuttorniaq: hunter which hunts uuttoq.

/uuttoq-niar seal-hunt/

\section{Tunumiisut (Eastern Greenlandic)}

The Tunumiisut vocabulary of terms related to "ice" was collected in the course of a wider study of the structure of the Tunumiisut lexicon (Tersis 2008). This study was conducted between 1990 and 2000 in collaboration with speakers from Tasiilaq in eastern Greenland. Among the most important contributors were Kathrine Svanholm, Isais Kuitse, Elisa Maqi, and Marie Otuaq.

aakkaqniq: melted sea ice (which becomes soft and dark, hence rotten). /aaC-kkaq-niq melt-causative-abstract notion/ 
aaqniaat: harpoon for hunting seal on ice

/aaq-niaq-Vt? crawl-intention-means of/

ammatitaq: hole in sea ice built by narwhal or sea mammal

Cf. amma- be open

aniq: gap in sea ice or channel ice

aniqsiq: floating sheet of ice broken off from ice floe and coming out of fjord Cf. ani- go out

apusiiq: inlandsis, ice cap

aputtiq: snow bridge hiding crevasses in melting ice

Cf. aput snow on ground

attiq: seal's breathing hole in ice

attisuut: harpoon for hunting seal at breathing hole

/attiq-qsuq-Vt hole-use-means of/

ayaappiaq: icepick

Cf. ayaC push

iimaataq: part of harpoon formerly used for hunting seal on ice /iimaq-Vtaq foreshaft of harpoon- look like/

imaaq-: be ice-free (sea)

Cf. imaq contents, sea

imaayuk: mixture of sea water and melted ice, treacle, molasses

Cf. imaq contents, sea

ima-qa-nngitaq: there is no sea (only ice)

/sea-have-negative.ind.3sg/

ima-qqi-qaaq: sea is ice free, calm

/imaq-qqiC-qaa-wuq sea-do well-intensive-ind.3sg/

imaqniqsaq: unfrozen part of sea, opening in ice

Cf. imaq contents, sea

ingiiNiaq: three-footed stool used by hunter at breathing hole /ingiiq-ngiaq thrust (hips forward)-place/

issinniq: pieces of overlapping sea ice on shore

/issiC-niq lean forward- abstract notion/

Cf. iiC-sit down 
issiwaqtiit: harpoon for hunting seal through hole in ice

Cf. Proto Eskimo: *iyyuR - "poke head out for a look" (Fortescue et al. 1994:150)

itaaqniaat: wooden or bone ice scraper used to remove coat of ice from kayak /itaaqniq-Vyaq-Vt hoarfrost-remove-means of/

itaaqniq: hoarfrost, rime

Cf. itiC- inside

ititiaq: iceberg

Cf. Proto Eskimo: *ilu “inside", *ilul(1)iRaR "s.th.inside?" (Fortescue et al. 1994:

128-129)

kattiitaq: floating pan of dark ice (small size)

/kattiq-Vtaq ice-look like/

kattiq: floating pan of fresh-water ice

kattiwat: small fragment of iceberg

kikkitiq: breathing hole in ice where seal comes up

kinniq: ice edge (where ice and sea meet), fast-ice edge

maniitsiq: glacier berg (irregularly shaped iceberg)

/maniC-nngit-siq be flat-negative-attributive/

maniittat: hummocky ice

/maniC-nngit-tat be flat-negative-resultative.pl/

manniNaq: tabular berg (flat-topped iceberg)

Cf. maniC- be flat

nappat: small floes, flatter pieces of sea ice

nitak: 1 . freshwater ice 2 . ice coating

nutaqniq: new ice (layer of thin, pliable ice)

/nutaaq-niq new- abstract notion/

pattingatiq: seal lying on ice

/pattiq-nga-tiq lie down-resultative-attributive/

pukkuwik: breathing hole made in ice by seal

Cf. -wik place

qaaNuq: shore sea ice

qii- freeze 
qiissiiaq: thing frozen, (meat, fish, etc.)

/qii-ssiiaq freeze-left/

qinitiaq: slush ice (dense mass floating on water after snowfall)

qassimatiq: (ringed) seal up on ice

/qassi-ma-tiq climb up on ice-state-attributive/

qiqqiniq: mass of freshwater ice encased in piece of seawater ice

qiqsaqniq: ice cover frozen after thaw

qiqsiqqaqtaq: ice cover hardened by wind

quasaq(-): 1 . bare ice 2 . be slippery

saqpaq(-): 1. current (of water) 2. flow quickly (current)

sassat: hole in ice used by narwhal

sikaqniq: hard surface (snow, ice, bread, etc.)

/sikaq-niq be stiff- abstract notion/

siki-: freeze, ice up

sikiitaq(-): 1. thin ice on water, 2. skate (on ice)

sikiitaqattaaNisit: (ice) skate

/sikiitaq-qattaaq-ngisit skate on ice-repetitive-means of.pl/

sikiq: sea ice

siki-qa-nngitaq: there is no ice (ice-free area)

/ice-have-ind.negative. $3 \mathrm{sg} /$

siki-qa-qaaq: there is a lot of ice (thick ice)

/ice-have-intensive.ind.3sg/

siki-wiq-puq: sea ice goes away

/ice-remove-ind. $3 \mathrm{sg} /$

sikitaq: gray ice (new ice that can be broken by heave)

sikiwiit: ice pack, ice floe

/sikiq-tiwiit ice-big.pl/

siqmiq: freshwater ice from mainland

siqmiqsuaq: ice cap

/siqmiq-suaq ice-big/ 
tuaq: pack ice, (thick) motionless sea ice, ice which has thickened for only one winter

tukkaqtiit: ice pick

/tukkaq-tiq-Vt thrust in to make hole-repetitive-means of/

tuuq: ice pick

Acknowledgments Nicole Tersis wants to thank particularly Kathrine Svanholm who was a close collaborator on the Tunumiisut lexicon from 1990 to 2000, and also Isais Kuitse, Elisa Maqi,and Marie Otuaq who were kind enough to lend their assistance during the fieldwork in Tasiilaq,Eastern Greenland. She is also grateful to Naja Trondhjem, Greenlandic linguist at the University of Copenhagen, for helping analyze words from Western Greenland. Fieldwork in Greenland andDenmark was funded by the National Center for Scientific Research-CNRS (LACITO Laboratory for Oral Tradition Languages and Civilizations and CELIA- Center for the Study of he IndigenousLanguages of The Americas). Raymond Boyd (CNRS, LLACAN Laboratory for Languages andCultures of Black Africa) was helpful with the translation of the Tunumiisut ice lexicon into English. Pierre Taverniers is grateful to Aka, Jakob, Thora, and Zacharias Tobiassen for kindlysharing their knowledge about the ice terminology, and also to Igor Krupnik and Shari Gearheard for their helpful comments.

\section{References}

Berthelsen, C., Jacobsensen, B., Petersen, R., Kleivan, I., and Rischel, J. 2004 (1977 first edition).Oqaatsit, Kalaallisuumiit Qallunaatuumut/Grønlandsk Dansk Ordbog, Nuuk, Ilinniusiorfik.

Dorais, L.-J. 2003. Inuit Uqausiqatigiit. Inuit Languages and Dialects. Iqaluit: Nunavut Arctic College.

Fortescue, M., Jacobson, S.A., and Kaplan, L., 1994. Comparative Eskimo Dictionary with Aleut Cognates, Fairbanks, University of Alaska, Alaska Native Language Center Press, Research Papers 9.

Gessain, R., Dorais, L.-J., and Enel, C. 1986. Vocabulaire du Groenlandais de l'est, Paris, Documents du Centre de Recherches Anthropologiques du Musée de l'Homme 5.

Mahieu, M.-A. and Tersis, N. (eds.), 2009. Variations on Polysynthesis: The Eskaleut Languages, Typological Studies in Language. Amsterdam/Philadelphia: John Benjamins. Robbe, P. and Dorais, L.-J. 1986. Tunumiit oraasiat/Tunumiut oqaasii/Det østgrønlandske sprog/The East Greenlandic Inuit Language/La langue inuit du Groenland de l'Est, Québec, Université Laval, Nordicana 49.

Sadock, J. 2003. A Grammar of Kalaallisut (West Greenlandic Inuttut). Languages of the World/Materials 162, Lincom Europa.

Schultz-Lorentzen, C.W. 1927 (reprint 1967). Dictionary of The West Greenland Eskimo Language. Copenhagen: Meddelelser om Grønland.

Tersis, N. 2008. Forme et sens des mots du tunumiisut, lexique inuit du Groenland oriental. Louvain, Paris: Peeters.

Trondhjem, N.F. 2009. The marking of past time in Kalaallisut, the Greenlandic language. In Mahieu, M.-A. and Tersis, N. (eds.), Variations on Polysynthesis: The Eskaleut Languages, Typological Studies in Language. Amsterdam/Philadelphia: John Benjamins, pp. 171-182. Victor, P.-E. and Robert-Lamblin, J. 1989. La civilisation du phoque. Jeux, gestes et techniques des Eskimo d'Ammassalik, vol 1. Paris: Armand Colin-Raymond Chabaud. Victor, P.-E. and Robert-Lamblin, J. 1993. La civilisation du phoque. Légendes, rites et croyances des Eskimo d'Ammassalik, vol 2. Paris: Raymond Chabaud. 